\title{
KEGAGALAN PEMBERIAN ASI EKSKLUSIF PADA BAYI USIA 0-6 BULAN DI WILAYAH PUSKESMAS MANGGIS I KARANGASEM
}

\author{
Arya Mahendra Yogantara ${ }^{1}$, I Ketut Sudinda ${ }^{2}$ \\ Program Studi Pendidikan Dokter Fakultas Kedokteran Universitas Udayana ${ }^{1}$ \\ Kepala Puskesmas Manggis I Kabupaten Karangasem ${ }^{2}$
}

\begin{abstract}
ABSTRAK
\end{abstract}
Salah satu upaya untuk meningkatkan status gizi bayi adalah dengan memberikan air susu ibu (ASI). ASI mengandung antibodi dari ibu yang membantu memerangi penyakit, untuk itu pemberian dari ASI pada bayi harus dilakukan sejak dini dan diberikan secara eksklusif. Departemen Kesehatan melalui Keputusan Menteri Kesehatan No: 450/Menkes/SK/IV/2004 menetapkan bahwa semua tenaga kesehatan agar menginformasikan kepada semua ibu yang baru melahirkan untuk memberikan ASI secara eksklusif. Tujuan dari penelitian ini adalah untuk mengetahui gambaran kegagalan dan pengetahuan ibu tentang pemberian ASI eksklusif di wilayah kerja Puskesmas Manggis I Karangasem. Penelitian ini mempergunakan rancangan penelitian deskriptifdengan pendekatan cross sectional. Jumlah sampel yang digunakan sebesar 50 orang dengan kriteria semua ibu yang memiliki bayi berumur 0-6 bulan yang gagal memberikan ASI Eksklusif di wilayah kerja Puskesmas Manggis I. Penelitian ini dilaksanakan mulai bulan September hingga bulan Oktober 2013. Hasil didapatkan pengambil keputusan saat ibu memberikan makanan tambahan pendamping ASI yang menjadi penyebab kegagalanadalahpetugas kesehatan sendiri sebanyak $56 \%$, dan yang kedua adalah keputusan ibu sendiri sebanyak 54\%. Pengetahuan ibu mengenai ASI eksklusif didapatkan pengetahuan kurang (46\%), pengetahuan cukup (28\%), dan pengetahuan baik (26\%).

Kata kunci: ASI eksklusif, petugas kesehatan, pengetahuan, puskesmas

\section{THE FAILURE OF THE PROVISION AND MOTHER'S KNOWLEDGE ABOUT BREASTFEEDING EXCLUSIVELY ON THE BABY AGE 0-6 MONTH IN THE REGION MANGGIS I PRIMARY HEALTH CARE}

\begin{abstract}
One of many efforts to improve nutrition status of baby is by giving milk the mother (breastfeeding).Breastfeeding containing antibodies from the mother who helped fight against disease, for that provision of breastfeeding in infants should be done early and given exclusively. The department of health through a decree of the minister of health no: 450 / menkes / sk / iv / 2004 determined that all health workers to inform all the mothers that just given birth to give breast-fed exclusively.The aim of this research is to find a failure and the knowledge about granting exclusive breast-fed in the work area of Manggis IKarangasem primary health care.The total sample used as much as 50 people with the criteria for all the mothers that having a baby was 0-6 months fail to provide exclusive breastfeeding in the work area of Manggis I primary health care.Cross sectional design is used in descriptive observational research. This research take place from september until october 2013. The result was obtained the decision makers when mom give supplementary food breastfeeding who mentors be the cause of failure is own health officers as many as $56 \%$ and the second was the decision of the mother own about $54 \%$.The mother's knowledge regarding breastfeeding exclusive been gained knowledge less ( $46 \%$ ) knowledge enough ( $28 \%$ ) and knowledge of good ( $26 \%$ ).

Keywords:Exclusive breastfeeding, health workers, knowledge, primary health care

\section{PENDAHULUAN}

Masih tingginya prevalensi malnutrisi dan kejadian infeksi merupakan faktor risiko yang berkontribusi paling signifikan terhadap angka kematian bayi. ${ }^{[1]}$ Salah satu upaya untuk meningkatkan status gizi bayi adalah dengan memberikan air susu ibu (ASI) yang mengandung antibodi dari ibu untuk membantu memerangi penyakit.Untuk itu pemberian dari ASI

pada bayi harus dilakukan sejak dini dan diberikan secara eksklusif. ${ }^{[2]}$ Menurut peraturan pemerintah No 33 tahun 2012, ASI eksklusif merupakan ASI yang diberikan kepada bayi sejak dilahirkan selama 6 bulan tanpa menambahkan dan atau mengganti makanan atau minuman lain. ${ }^{[3]}$ Banyak penelitian yang membuktikan bahwa menyusui secara eksklusif melindungi bayi secara signifikan dari diare, infeksi
\end{abstract}


saluran pernapasan akut (ISPA), dan sepsisneonatorum(penyebaran mikroba patogen atau toksinnya ke dalam darah atau jaringan bayi barulahir hingga empat minggu). ${ }^{[4]}$

Bayi yang tidak mendapat ASI eksklusif memiliki risiko kematian karena diare 3,94 kali lebih besar dibandingkan bayi yang mendapat ASI eksklusif. ${ }^{[5]}$ Begitu pula penelitian di Amerika Latin menyatakan bahwa $13,9 \%$ dari semua penyebab kematian bayi dapat dicegah dengan ASI eksklusif untuk 3 bulan pertama kehidupan. ${ }^{[6]}$ Berdasarkan The WHO Global Data Bank on Breastfeeding, proporsi bayi yang mendapatkan ASI eksklusif adalah sebesar $35 \%$ didapat dari 94 negara di dunia atau sekitar 65\% populasi bayi yang berusia $<12$ bulan di seluruh dunia. ${ }^{[2]}$ Menurut laporan Riset Kesehatan Dasar tahun 2010 di Indonesia didapatkan bayi yang masih menerima ASI eksklusif sampai berusia 5 bulan sebesar 15,3\% dan secara keselurahan sebesar $28,3 \%$ dari bayi di bawah enam bulan menerima ASI secara eksklusif. ${ }^{[7]}$

Penelitian ini bertujuan untuk mengetahuigambaran kegagalan dan pengetahuan ibu dalam pemberian ASI eksklusif di wilayah kerja Puskesmas Manggis I, sedangkan tujuan khususnya adalah mengetahui usia anak saat mulai diberikan makanan selain ASI, pengambil keputusan dalam penghentian/tidak memberikan ASI, mengetahui apakah petugas kesehatan di Puskesmas memberikan arahan untuk memberikan ASI eksklusif dan mengetahui pengetahuan ibu tentang manfaat ASI eksklusif baik bagi ibu maupun bayinya.

\section{METODE PENELITIAN}

Penelitian ini merupakan penelitian deskriptif dengan pendekatan cross sectional. Penelitian dilakukan di Puskesmas Manggisl Kabupaten Karangasem pada bulan September sampai Oktober 2013dengan jumlah sampel sebanyak 50 orang. Populasi penelitian ini adalah semua ibu yang memiliki bayi berumur 0-6 bulan yang gagal memberikan ASI Eksklusif di wilayah kerja Puskesmas Manggis I.

Penelitian dilakukan terhadap aspek pengetahun dan kegagalan pemberian ASI. Peneliti menggunakan metodesimple random samplingdi mana pengambilan sampel dilakukan pada setiap ibu yang memiliki bayi berumur $\leq 6$ bulan yang gagal memberikan ASI secara eksklusif yang terpilih secara acak.Sampel diambil berdasarkan data sekunder yaitu dataMonitoring dan Evaluasi Program Gizi UPT Puskesmas Manggis I bulan Agustus tahun 2013. Pengumpulan data dilakukan dengan wawancara menggunakan pedoman wawancara yang dibuat sesuai dengan konsep teori tentang ASI eksklusif. Untuk data pengetahuan ibu dinilai berdasarkan 10 item yang terdapat pada pertanyaan kuisioner kemudian dihitung nilai masing-masing responden. Menurut Budiarto, setiap pertanyaan yang dikelompokkan ke dalam bentuk pengetahuan dihitung persentasenya dengan cara membagi frekuensi (f) dengan seluruh pertanyaan (N) kemudian dikalikan 100 persen. ${ }^{[9]}$ Penggolongan pengetahuan baik, cukup dan kurang berdasarkan persentase hasil dengan kriteria baik, cukup dan kurang berturut-turut lebih dari 76 persen, 56 sampai 76 persen dan kurang dari 56 persen. Kegagalan pemberian ASI eksklusif dilihat dari pengaruh apakah berasal dari luar ataupun dalam lingkungan ibu. Peranan petugas kesehatan dibagi menjadi aktif maupun pasif dinilai dari pertanyaan pada kuisioner.

Langkah-langkah dalam pengumpulan data yang dilakukan yaitu mengurus izin penelitian, mencari sampel penelitian, menjelaskan maksud dan tujuanpenelitian serta pelaksanaan wawancara, penandatanganan lembar persetujuan menjadi responden dan melakukan wawancara terpimpin dengan responden.

\section{HASIL}

Lokasi penelitian beralamat di desa-desa wilayah Kecamatan Manggis Kabupaten Karangasem. Wilayah yang menjadi lingkup kerja Puskesmas Manggis I yaitu Desa Manggis, Ulakan, Padang Bai,Antiga, Antiga Kelod dan Gegelang. Jumlah penduduk di wilayah kerja Puskesmas Manggis I tahun 2010 adalah 31.571 orang. Jumlah bayi yang gagal mendapatkan ASI secara eksklusif sebanyak 78 bayi dari bulan September hingga Oktober 2013, dengan menggunakan rumus besar sample didapatkan besar sampel minimal yang diperlukan dalam penelitian ini adalah sebesar 43,04 orang. Peneliti menetapkan besar sampel dalam penelitian ini adalah 50 orang. Penambahan jumlah sampel dilakukan untuk menghindari berkurangnya sampel jika ada yang drop out karena berbagai alasan.

Pengetahuan responden tentang ASI eksklusif dapat dilihat pada tabel 1 . Tabel 1 menunjukkan bahwa responden yang memiliki tingkat pengetahuan kurang merupakan jumlah terbanyak yaitu sebanyak 23 responden (46\%), responden yang memiliki pengetahuan baik jumlahnya lebih kecil daripada tingkat pengetahuan cukup. 
Berdasarkan tabel 2 dapat dilihat bahwa sebagian responden (50\%) memiliki pengetahuan cukup tentang definisi ASI eksklusif, dan setengahnya lagi (50\%) memiliki pengetahuan kurang. Untuk manfaat ASI eksklusif bagi bayi sebagian besar responden memiliki pengetahuan yang cukup (68\%) dan sebagian kecil berpengetahuan kurang (32\%). Sebagian besar responden memiliki pengetahuan yang cukup mengenai perbendaan antara ASI dengan susu formula (94\%) dan yang kurang sebanyak 6 persen. Mengenai pengetahuan tentang cara penyimpanan ASI yang benar sebanyak 52 persen memiliki pengetahuan kurang dan 48 persen cukup.

Tabel 3 menunjukkan Peran Petugas Kesehatan Dalam Memberikan Arahan Kepada Responden Untuk Memberikan ASI Secara Eksklusif. Peran petugas kesehatan dikelompokkan menjadi dua, yaitu aktif dan pasifdalam memberikan arahan kepada reponden dalam memberikan ASI secara eksklusif. Pada analisis data didapatkan peran petugas kesehatan yang pasif dalam pemberian ASI secara eksklusif lebih dominan dibandingkan dengan yang aktif.

Tabel 4 menunjukkan pengambil keputusan saat ibu memberikan makanan tambahan pendamping ASI yang menjadi penyebab kegagalan. Pengambil keputusan adalah seseorang yang memberikan keputusan penghentian/tidak memberikan ASI eksklusif yang menjadi penyebab kegagalan ASI secara eksklusif. Pengambil keputusan yang terbanyak sebagai penyebab kegagalan adalah keputusan dari petugas kesehatan sendiri sebanyak $56 \%$, dan yang kedua adalah keputusan ibu sendiri sebanyak $54 \%$.

Tabel 5 menggambarkan Tabulasi silang antara siapa yang menyarankan makanan pertama kali dengan makanan bayi pertama kali dan dibekali susu formula atau tidak. Berdasarkan jawaban pada pertanyaan peran petugas kesehatan didapatkan responden cenderung menjawab bidan penolong pada pertanyaan siapa yang menyarankan memberikan makanan pertama bagi bayi yaitu sebanyak 42 responden. Berdasarkan hasil tabulasi silang antara siapa yang menyarankan pemberian makanan pertama pada bayi dengan apakah dibekali susu formula atau tidak dan makanan bayi pertama kali yang diberikan didapatkan dari 42 responden yang disarankan oleh bidan penolong 25 responden diantaranya disarankan susu formula dan 26 diantaranya dibekali dengan susu formula.

Tabel 1. Distribusi frekuensi responden berdasarkan tingkat pengetahuan ibu tentangASI eksklusif di wilayah kerja Puskesmas Manggis I

\begin{tabular}{lcc}
\hline Tingkat Pengetahuan Ibu & Frekuensi & Presentase (\%) \\
\hline Pengetahuan kurang & 23 & 46 \\
Pengetahuan cukup & 14 & 28 \\
Pengetahuan baik & 13 & 26 \\
\hline Total & 50 & 50 \\
\hline
\end{tabular}

Tabel 2. Distribusi frekuensi tingkat pengetahuan responden berdasarkan bagian pengetahuan tentang ASI eksklusif

\begin{tabular}{clcc}
\hline \multirow{2}{*}{ No. } & Tingkat Pengetahuan Responden & & Jumlah \\
\cline { 3 - 4 } & Definisi ASI eksklusif & Frekuensi & Persentase (\%) \\
\cline { 3 - 4 } & Kurang & & 50 \\
& Cukup & 25 & 50 \\
\cline { 2 - 4 } & Total & 25 & 100 \\
\hline 2 & Manfaat ASI eksklusif bagi bayi & 50 & 32 \\
& Kurang & & 68 \\
& Cukup & 16 & 100 \\
\cline { 2 - 4 } & Total & 34 & 6 \\
\hline
\end{tabular}




\begin{tabular}{llcc}
\hline & Cukup & 47 & 94 \\
\cline { 2 - 4 } & Total & 50 & 100 \\
\hline 4 & Penyimpanan ASI & & 52 \\
& Kurang & 26 & 48 \\
\cline { 2 - 4 } & Cukup & 24 & 100 \\
\cline { 2 - 4 } & Total & 50 & \\
\hline
\end{tabular}

Tabel 3. Peran Petugas Kesehatan Dalam Memberikan Arahan Kepada Responden Untuk Memberikan ASI Secara Eksklusif

\begin{tabular}{lcc}
\hline Peran petugas kesehatan & Frekuensi & Persentase (\%) \\
\hline Aktif & 16 & 32 \\
Pasif & 32 & 68 \\
\hline Total & 50 & 100 \\
\hline
\end{tabular}

Tabel 4.distribusi pengambil keputusan saat ibu memberikan makanan tambahan pendamping ASI yang menjadi penyebab kegagalan

\begin{tabular}{lccc}
\hline Pengambil keputusan & & Frekuensi & Persentase (\%) \\
\hline Keputusan sendiri & Ya & 27 & 54 \\
& Tidak & 23 & 46 \\
\hline \multirow{2}{*}{ Suami } & Total & 50 & 100 \\
\hline & Ya & 3 & 6 \\
& Tidak & 47 & 94 \\
\hline Petugas Kesehatan & Total & 50 & 100 \\
& Ya & 28 & 56 \\
& Tidak & 22 & 44 \\
\hline Orang tua/ mertua & Total & 50 & 100 \\
& Ya & 3 & 6 \\
\hline & Tidak & 47 & 94 \\
\hline Tetangga & Total & 50 & 100 \\
& Ya & 2 & 4 \\
\hline & Tidak & 48 & 96 \\
\hline
\end{tabular}

Tabel 5. Tabulasi silang antara siapa yang menyarankan makanan pertama kali dengan makanan bayi pertama kali dan dibekali susu formula atau tidak

\begin{tabular}{|c|c|c|c|c|c|c|}
\hline & & & $\begin{array}{c}\text { Inisiatif Diri } \\
\text { Sendiri }\end{array}$ & Bidan Penolong & Suami & Total \\
\hline Dibekali & Susu & Ya & 2 & 26 & 1 & 29 \\
\hline \multirow[t]{2}{*}{ Formula } & & & $6,9 \%$ & $89,7 \%$ & $3,4 \%$ & $100 \%$ \\
\hline & & Tidak & $\begin{array}{c}5 \\
23,8 \%\end{array}$ & $\begin{array}{c}16 \\
76,2 \%\end{array}$ & $\begin{array}{c}0 \\
0 \%\end{array}$ & $\begin{array}{c}21 \\
100 \%\end{array}$ \\
\hline \multirow[t]{2}{*}{$\begin{array}{l}\text { Makanan } \\
\text { Pertama Kali }\end{array}$} & Bayi & ASI & $\begin{array}{c}5 \\
22,7 \%\end{array}$ & $\begin{array}{c}17 \\
77,3 \%\end{array}$ & $\begin{array}{c}0 \\
0 \%\end{array}$ & $\begin{array}{c}22 \\
100 \%\end{array}$ \\
\hline & & Susu Formula & $\begin{array}{c}2 \\
7,1 \%\end{array}$ & $\begin{array}{c}25 \\
89,3 \%\end{array}$ & $\begin{array}{c}1 \\
3,6 \%\end{array}$ & $\begin{array}{c}28 \\
100 \%\end{array}$ \\
\hline Total & & & $\begin{array}{c}7 \\
14 \%\end{array}$ & $\begin{array}{c}42 \\
84 \%\end{array}$ & $\begin{array}{c}1 \\
2 \%\end{array}$ & $\begin{array}{c}50 \\
100 \%\end{array}$ \\
\hline
\end{tabular}




\section{DISKUSI}

Pada penelitian ini didapatkan dari seluruh responden, lebih dari setengahnya memiliki tingkat pengetahuan baik dan cukup. Dari hasil analisis dapat disimpulkan bahwa dari kegagalan pemberian ASI secara eksklusif, tidak ada kecenderungan seluruhnya berpengetahuan kurang. Hasil penelitian ini berbeda dengan penelitian yang dilakukan oleh Ambarwati (2004) di Kecamatan Banyumanik dimana didapatkan dari seluruh kegagalan pemberian ASI eksklusif lebih banyak terjadi pada ibu dengan pengetahuan tentang ASI yang kurang dari pada ibu yang memiliki pengetahuan tentang ASI yang lebih baik. ${ }^{[9]}$ Sesuai dengan program yang dijalanakan oleh puskesmas manggis I berupa peningkatan pengetahuan ibu mengenai ASI eksklusif sudah baik, namun pengetahuan mengenai cara penyimpanan ASI yang benar masih kurang. Mengenai hal ini perlu melakukan usaha untuk mengubah perilaku ibu yang bekerja sehingga penyimpanan ASI dapat diterapkan seperti melakukan praktik mengenai cara penyimpanan ASI serta penyuluhan risiko dan bahaya pemberian makanan atau minuman tambahan selain ASI.

Secara umum didapatkan peran petugas kesehatan yang pasif dalam pemberian ASI secara eksklusif lebih dominan dibandingkan dengan yang aktif. Dari penelitian didapatkan peran petugas kesehatantentang pemberian ASI eksklusif pada responden yang pasifsebanyak $68 \%$ dan yang aktif $32 \%$.Hasil analisis data selanjutya dapat disimpulkan bahwa petugas kesehatan sangat berpengaruh terhadap terjadinya kegagalan pada pemberian ASI secara eksklusif. Penelitian ini berbeda dengan hasil penelitian yang dilakukan oleh Kusnadi (2007) yang menyatakan bahwa penolong persalinan dalam hal ini petugas kesehatan tidak menunjukan hubungan yang bermakna dengan pemberian ASI eksklusif. ${ }^{[10]}$

Data penelitian selanjutnya didapatkan bahwa dari seluruh responden yang mendapatkan susu formula pertama kali sebagian besar disarankan oleh bidan penolong dan waktu pulangnya dibekali dengan susu formula. Pengetahuan responden bisa bersumber dari petugas kesehatan maupun dari orang-orang dilingkungannya sendiri. Dari penelitian ini didapatkan data bahwa responden yang mendapatkan penjelasan dari petugas kesehatan (bidan dan dokter) memiliki tingkat pengetahuan baik dan cukup lebih banyak dari pada yang pengetahuan kurang. Analisis data menyimpulkan ibu yang mendapatkan informasi dari petugas kesehatan cenderung memiliki pengetahuan baik tentang ASI eksklusif.

Mengenai hal ini, upaya membangun peran petugas kesehatan yang aktif penting untuk dilakukan. Proses ini dapat dilakukan melalui meningkatkan kesadaran petugas kesehatan akan pentingnya pemberian ASI bagi bayi yang baru lahir, dan jangan mengejar keuntungan dari pemberian susu formula, kesadaran itu juga harus diikuti dengan praktek Inisiasi Menyusu Dini yang baik dan benar. Hal ini bisa dilakukan dengan mengadakan pelatihan-pelatihan kembali kepada petugas kesehatan tentang pemberian ASI eksklusif dan IMD sehingga kesadaran petugas kesehatan dalam menerapkan hal tersebut lebih baik.

Pengambil keputusan adalah seseorang yang memberikan keputusan penghentian/tidak memberikan ASI eksklusif yang menjadi penyebab kegagalan ASI secara eksklusif. Pengambil keputusan yang terbanyak sebagai penyebab kegagalan adalah keputusan dari petugas kesehatan sendiri sebanyak 56\%, dan yang kedua adalah keputusan ibu sendiri sebanyak 54\%. Padahal Peranan petugas kesehatan disini sangat penting dalam melindungi, meningkatkan, dan mendukung usaha menyusui dari ibu. Sebagai individu yang bertanggung jawab dalam gizi bayi dan perawatan kesehatan, petugas kesehatan mempunyai posisi unik yang dapat mempengaruhi keputusan dari ibu.

Mengenai hal ini, perlu kembali meningkatkan kesadaran petugas kesehatan dalam hal ini bidan penolong untuk tidak menyarankan ibu memberikan susu formula kepada bayinya segera setelah lahir. Solusi yang lain yang bisa dilakukan adalah pengawasan secara ketat oleh pihak terkait dalam hal penggunaan susu formula dimasyarakat.

\section{PENUTUP}

Simpulan

Pada penelitian ini pengetahuan responden tentang ASI eksklusif sebagian besar adalah kurang, dikuti dengan pengetahuan cukup dan baik. Keputusan penghentian/tidak memberikan ASI eksklusif lebih banyak dianjurkan oleh petugas kesehatan yang kemudian diikuti oleh keputusan ibu sendiri. Pada penelitian ini Petugas kesehatan berperan pasif dalam memberikan arahan kepada 
ibu untuk memberikan ASI eksklusif kepada bayinya.

\section{Saran \\ Kepada Puskesmas Manggis I khususnya pemegang program Upaya Promosi Kesehatan dan Upaya Perbaikan Gizi Masyarakat agar melaksanakan penyuluhan mengenai ASI eksklusif dengan tujuan meyakinkan ibu menyusui bahwa makanan bayi cukup ASI saja sampai bayi berusia 6 bulan, mengajarkan ibu untuk melakukan teknik menyusui yang benar sehingga produksi ASI dapat optimal, dan mengajarkan ibu teknik penyimpanan ASI sehingga ibu yang bekerja dapat tetap memberikan ASI kepada bayi. Selain hal itu, pengetahuan dan peran petugas kesehatan dapat dioptimalkan sebagai penyuluh dan pengawas pemberian ASI eksklusif.}

\section{DAFTAR PUSTAKA}

1. Hermina dan Arfiansyah.2010. "Hubungan Praktik Pemberian Asi Eksklusif dengan Karakteristik Sosial, Demografi dan Faktor Informasi Tentang Asi dan MP-ASI (Studi di Kota Padang dan Kabupaten Solok Provinsi Sumatera Barat)". Buletin Penelitian Sistem Kesehatan, 13. 353-360

2. WHO. 2011. Exclusive Breastfeeding For Six Months Best for Babies Everywhere. http://www.who.int/mediacentre/news/ statements/2011/breastfeeding_ 20110115/en/. diakses tanggal 1 September 2013

3. Manajemen Laktasi. 2005. Departemen Kesehatan RI. Jakarta

4. Helen Keller Worldwide. "Breastfeeding and Complementary Feeding Practices in Indonesia". Annual Report.2002

5. Betran AP, Onis M, Lauer JA, Villar J. 20012001. "Ecological Study of Effect of Breast Feeding on Infant Mortality in Latin America". Med J,323. 1-5

6. Monterrosa, et al. 2008. "Predominant BreastFeeding from Birth to Six Months Is Associated with Fewer Gastrointestinal Infections and Increased Risk for Iron Deficiency among Infants". J. Nutr,138. 1499-1504

7. Badan Penelitian dan Pengembangan Kesehatan. Riset Kesehatan Dasar 2010. Jakarta: Kementerian Kesehatan RI.

8. Budiarto, E. 2002. "Biostatistika untuk Kedokteran dan Kesehatan Masyarakat". Jakarta: EGC.

9. Ambarwati, R. 2004. Faktor yang Berhubungan dengan Kegagalan Pemberian ASI Eksklusif di Puskesmas Padangsari Kabupaten Ungaran. Skripsi Fakultas Kesehatan Masyarakat Universitas Diponegoro, Semarang.

10. Kusnadi. 2007. Analisis faktor-faktor yang berhubungan dengan pemberian ASI eksklusif di kabupaten tanggerang tahun 2006. Tesis. Fakultas kesehatan Masyarakat Universitas Indonesia. Jakarta 